\title{
THE RELATIONSHIP BETWEEN EMPLOYEE ENVIRONMENTAL AWARENESS AND CURRENT ENVIRONMENTAL MANAGEMENT SYSTEM
}

\author{
Bolesław Goranczewski* $\odot$ http://orcid.org/0000-0001-9081-083X
}

\begin{abstract}
Background. Many publications have studied environmental management systems. Once a system is implemented and maintained, it should affect employee environmental awareness - the question is to what extent it does so. To date, published studies have defined awareness and highlighted its importance. The author, as a practitioner, was interested in whether the positive opinion about the system expressed in the system documentation (audit reports) was relevant for the development of environmental awareness of managers and employees.

Research aims. Therefore, the purpose of this article was to establish the relationship between the state of the environmental management system and the environmental awareness of users. It was recommended to introduce surveys to raise awareness and improve the system.

Methodology. Literature review and surveys were used to collect the data.

Findings. The surveys showed that the vast majority of employees want their organization to be safe for the environment. But in practice, many employees do not know the environmental objectives or environmental improvement plans. This means that the system is not optimally maintained. Decision-makers rely on the reports from environmental audits and reviews to learn about the need to improve environmental awareness. In addition to analyzing the documentation, surveys are needed in an organization to understand the employees' feedback.
\end{abstract}

Keywords: environmental awareness, industrial environmental systems, environmental management, chemical industry.

JEL Codes: J23, O15, R11.

* Opole University. E-mail: boleslaw.goranczewski@uni.opole.pl. 


\section{INTRODUCTION}

The concept of environmental awareness was already known in the nineteenth century (Specq, 2016). In management, however, the term came into being only when the ISO 14001 standards appeared. Awareness is one of the so-called support criteria and co-exists with criteria including skills, resources, documented information, and communication. Awareness influences the management of environmental aspects and has a significant impact on the "green behaviour" of employees (Safari et al., 2018). It is also important for making pro-environmental decisions (Papagiannakis \& Lioukas, 2018).

One way to influence environmental awareness is employees' active participation in the maintenance and improvement of environmental management systems. Recently, much has been said about the impact of these systems on employee awareness and behavior (e.g., Bugdol, Puciato \& Borys, 2020). This raises the question to what extent the status of the system itself is related to the environmental awareness of employees. This article analyses the awareness understood as employees' knowledge of the correct actions taken within the environmental management system.

\section{THE STATE OF STUDIES IN THE LITERATURE}

Awareness is one of the criteria of the environmental management system, and more precisely it is an element of so-called support. The standard recommends that people working under the supervision of an organization should be aware of the environmental policy, its objectives and their role in the implementation of various obligations (ISO 14001:2015.7.3). The term 'environmental awareness' refers to how an individual employee perceives (assesses) the impact of human activity on the environment (Kollmuss \& Agyeman, 2002). Based on the literature review, two groups of studies related to environmental awareness can be distinguished. The first group deals with its importance, and the second one is related to awareness-raising.

As regards the importance, it is emphasized that awareness:

- affects the management of environmental aspects (Tocan, 2016), 
- has a significant direct impact on employees' "green behaviour" (e.g., Safari et al., 2018),

- has an influence on pro-environmental decision-making - in addition to personal standards and responsibility assigned (Papagiannakis \& Lioukas, 2018),

- stimulates new consumption habits (Severo et al., 2019),

- is one of the factors of entrepreneurship (Giudici, Guerini \& Rossi-Lamastra, 2019).

The second group of studies concerns the raising of awareness. It is currently, recognized that awareness:

- is shaped through awareness training programs (Law, Hills \& Hau, 2017),

- should be one of the elements of environmental measurements (Alomari \& Ibraheem, 2019),

- can be one of the objectives of the educational process (Zeynep, 2020),

- requires appropriate public policies (Tursynbayeva et al., 2020),

- requires that employees be shown the benefits that can be gained from reducing the costs of environmentally friendly practices (e.g., Yucedag, Kaya \& Cetin, 2018).

\section{RESEARCH METHOD, PROBLEMS AND ASSUMPTIONS}

The survey was conducted in the spring of 2020 in one of the largest chemical sector companies in Poland, a member of a leading capital group in the sector. The company which was surveyed produces, distributes, sells and develops products offered on the market and employs over 1500 people. In addition to the surveys, during the period of the research, internal documentation and post-audit documentation were analyzed. The environmental management system in the surveyed company is integrated into a system covering also the quality of health and safety at work, TPM, product care, research and development, etc. All this has convinced the author of not disclosing the name of the company. However, it does not reduce the possibility of making cognitive conclusions or generalizations, including continuing research, e.g. utilitarian/practical conclusions can be deepened or made to inform the management about the causal relationships between the problems identified and diagnosed in the research. 
To solve the research problems specified in the latter part of the study, a classic combination of methods was used, and sources enabling data verification were selected. Therefore, it should be considered that the rule of triangulation both in terms of methodology and sources of information has been maintained. The research process includes a review of the literature on the subject to learn about the cognitive status of the studied issues, analysis of system and organizational documentation in the company under analysis and the method of surveying with a questionnaire.

I. The literature review covered the following databases: Academic Search Ultimate, Education Resources, EBSCO (according to, e.g., Easterby-Smith, Thorne \& Jackson, 2015).

II. Questionnaire surveys were conducted on a sample of $\mathrm{N}=309$ employees of the surveyed company. The respondents' positions in the organizational structure ran across a full-range profile. Starting from blue-collar positions employed directly in production (operation and use of chemical plants) to non-production positions, up to higher managerial positions. The sample surveyed constitutes approximately 20\% of employees. Quota sampling was used. The survey was disseminated across all units of the company's structure, ensuring the previously specified return rate. Due to the specificity of the company, the vast majority are men: $80 \%$. The structure of education is: higher, $39 \%$, secondary, $48 \%$, others have vocational and/or primary education, respectively. The two main age groups of respondents are people aged 36 to $49(40.9 \%)$ and over 50 years of age (36.9\%). The surveyed population included mostly people with long-term service: over 25 years for about $38 \%$ and between 11 and 24 years for $56.5 \%$. The survey used the $\mathrm{X}^{2}$ independence test and Pearson's contingency $(\mathrm{C})$ coefficient. The survey cafeteria included single-choice (disjunctive) and multiple-choice (conjunctive) questions. The questionnaire contained 40 questions on the general issue of environmental awareness, going beyond this article.

III. System documentation review.

For comparison purposes, system and management documentation was reviewed and compared to the survey results obtained. Available documentation from the last three years (2017-2019) included a total of about 180 documents. Among other things, the records included: documentation of the risk management system, rules for the 
identification of environmental aspects, environmental procedures, supervision of legal and other requirements, and management audit and review reports.

Based on the analysis of the literature, research questions were formulated:

1) To what extent is the environmental awareness of employees reflected in the activities undertaken in their organization?

2) What are the executives' knowledge about the need to improve environmental awareness (as a derivative of access to information and documentation)?

The researcher assumed that the vast majority of respondents wanted their organization to be safe for the environment. This was due to the specificity of the sector (chemistry) and the numerous pieces of training conducted. However, the status of the system itself leaves much to be desired. It is assumed that executives relied on the reports from audits and reviews to learn about the need to raise environmental awareness. This is due to the size of the organization, competition of certification bodies and their environmental protection services striving for excellence.

\section{RESULTS OF THE SURVEYS}

\section{Results of surveys}

One of the key pieces of information about the state of the system is how it provides interested employees with information about the degree of implementation of environmental systems, so that the employees could properly perform tasks and be aware of their further scope to perform. The respondents indicated that the most popular method of communication in this area is publishing on the Intranet (63\%). The next place was taken by meetings with the management staff at production departments (11\% of the respondents). At the same time, 185 people, which accounts for $60 \%$ of those responding to this question, indicated that information on the degree of achievement of the objectives is provided in real time. There were similar proportions for questions about the knowledge of plans to achieve environmental objectives. The responses indicated that 204 people, i.e. $67 \%$ of the sample knew these plans, while 102 people, representing $33 \%$ of the 
respondents said they did not. The respondents considered that the organization lacked pro-environmental motivation tools, as $86 \%$ of the respondents reported that the current remuneration system does not have such tools. Responses were spread evenly for the question if environmental system improvement activities can be proposed, where 157 people (52\%) declared that they had this possibility. The remaining 147 people said they had not. Respondents identified the following organizational barriers: instructions difficult to understand, 72 people; unclear division of powers and responsibilities related to tasks, 49 people; lack of proper procedures and instructions, 22 people; and improper organization of work in shifts, 16 people. Almost half, that is $47 \%$ of the respondents, stated that there were no organizational constraints. The respondents indicated the following technical and technological barriers in order of importance: heavily deteriorated plants and equipment, 155 people; the technology used and the inability to change it, 105 employees; the remaining interviewees listed equipment failure frequency or inadequate operational maintenance. Technical barriers were not noticed by 35 respondents. The respondents also pointed to communication limitations preventing the improvement of the environment and, consequently, the proper maintenance of the system. These obstacles are: unclear information, 97 people; difficulties in accessing information and documentation on the environment, 55 people (15\%); too few meetings on improvement, 55 people $(15 \%)$; insufficient information transferred by the executives, 43 people (11\%); others indicated that there were no such communication barriers. The majority of respondents, $60 \%$, indicated that the primary improvement tool - audit - is not useful.

Employees see the need for their workplace to contribute to reducing the negative impact on the environment, as confirmed by 245 people. In turn, 174 people report this need on a global scale. The respondents want the system to save money (cost-effectiveness). At the same time, they expect to benefit from these savings by receiving an appropriate salary. This is declared by 113 surveyed people. The majority, i.e. $57 \%$ of the people in the survey do not know whether the scope of the system covers products/semi-finished products manufactured at their workstations. They also do not know environmental objectives (the question was "do you know such objectives and if you do, give two examples"). The negative responses were $60 \%$ and the rest of responses confirmed they were familiar with the objectives, but most of them did 
not give examples. At the same time, $63 \%$ of the respondents said they knew the content of the environmental policy behind the objectives, but most of them did not know the objectives. Another inconsistency in responses is for the question about plans to achieve environmental objectives, which was responded positively by 204 people, while 102 interviewees thought differently. Vast majority of respondents, i.e. 272 people ( $89 \%$ of those who responded to the question) stated that they had not recently proposed ideas for reducing the negative impact on the environment. The 226 respondents (77\%) declare they know the environmental aspects (it is often difficult to understand the aspects, especially since the list of significant aspects in the surveyed organization is long). This is another example of a dichotomy in terms of knowledge of individual documents in the system structure. The policy is known. In fact, knowledge of the policy was demonstrated among the respondents and the objectives were no longer paradoxical despite the lack of knowledge of the objectives. The respondents indicated knowledge of the plans for achieving the objectives. Environmental aspects (the most difficult to understand) are known. The majority of the respondents, 206 of those who responded to this question (69\%), considered that the impact of their work on the environment was small. Responses were spread almost evenly for the question concerning the need to document events, activities related to system maintenance, which undoubtedly has a direct impact on environmental awareness. The 153 respondents (84\%) declared that products manufactured in their installations are safe for the environment.

The results of this survey (based on the $\mathrm{X}^{2}$ independence test) concerning the existing relationships between awareness and system support did not show statistical correlation (limit values $\mathrm{p}=0.003$, $c=0.3379)$. The level of awareness of system users raises concerns and doubts.

\section{Results of the documentation review}

For comparison purposes, audit documentation was reviewed and compared to the survey results obtained. The documentation showed that there was not a single non-compliance in the environmental area during the period under consideration. This was a special situation because in the previous periods there were discrepancies from the requirements as well as non-conformities outside the internal audit 
system (e.g., environmental incidents). They were identified on the basis of continuous monitoring, especially of emissions of harmful substances, where the reported exceedances were incidental, mainly related to deregulation of production installation processes. Another reason for the occurrence of non-conformities outside the system were emergencies. For these non-conformities, appropriate non-conformity sheets were not issued, while normally they are in order to implement improvement actions via the environmental system. Although non-conformities were immediately removed and the effectiveness of these actions was each time confirmed by appropriate measurements of emissions, this took place outside the system.

In the period under consideration, there were no preventive measures, which are a kind of hologram of system awareness, its exemplification. This is particularly important for the status (state) of the system.

The analysis of the results of external audits carried out under the jurisdiction of authorized bodies, including the Regional Inspectorate for Environmental Protection (WIOŚ), the District Governor's Office, has shown that in the analyzed period of 2017-2019, four irregularities were identified, resulting in recommendations, i.e. most lenient 'restrictions' according to the control bodies' classification of penalties.

In addition, the surveys carried out showed that:

- a cost effect was obtained i.e. failure to reach the value of the indicator in the period considered, this value being by $2.5 \%$ lower than planned,

- no financial penalties were imposed on the company in the environmental area in the period considered,

- the percentage share of the number of comments made to the adopted was $0 \%$,

- in the period considered, the total number of environmental aspects ranged from 1000 to 1100, including significant ones between 50 and 65 .

The review of audit documentation indicates a deep stability of the system, which may be positive but may also have negative connotations. The author did not aim for excessive criticism of the documentation submitted, but the conclusions of the review are as follows:

- the system is almost perfect according to the TQM classification resulting from quality awards, although at the same time it is known that perfection is only a model structure,

- the lack of improvement measures is of great concern. 


\section{DISCUSSION AND FUTURE RESEARCH}

The system is supporting the organization to comply with environmental regulations and the main attribute, which goes beyond the legal framework, is the improvement aimed to increase the ability to meet environmental requirements. Lack of improvement actions may be a result of system masters' intentional actions, i.e. environmental services maintaining the illusion of perfection.

Improvement is the main feature legitimizing the need to implement environmental systems. It covers mainly such areas as: chemical energy consumption in fuels, electricity consumption, and emission of harmful substances to the environment including gases from combustion processes or substances dumped into the soil. It is also the reduction of noise emissions, energy consumption waste and other activities. It is therefore essential to evaluate the improvement of environmental standards and to assess risk on a cyclical basis. Minimizing the carbon footprint of human activities, governed by specific environmental regulations, has become so important that the environmental standard separately covers the energy aspects in the energy management standard, complementary to the environmental standard. This proves the importance of the need to preserve the environment in today's world, especially in manufacturing and service processes.

The state of the system is closely related to users' environmental awareness. Therefore, social factors (environmental awareness, involvement in environmental issues) that require further research were important elements among determining factors in the case of industrial enterprises, in addition to those of a technical and economic or operational nature (condition of equipment and installations).

Below is a selection of these factors.

1) Effective communication on policy, objectives, resulting programs and environmental tasks (meetings, notice boards, pieces of training, other forms of exchanging views on the system and experiences, the cooperation of organizational units with relevant external and internal environmental services).

2) Suitable integration with properly designed and implemented incentive system including gratuities for activities and ideas for the improvement of the environment in the workplace. 
3) A common opportunity to develop initiatives and implement them to reduce the workplace's negative environmental impact.

4) Elimination of technical and organizational barriers preventing improvement of environmental processes and structures.

Appropriate status of the system, i.e. its proper maintenance based on high employee awareness, can "mediate" between the reduction of the organization's environmental impact and the cost optimization.

\section{CONCLUSIONS}

The vast majority of employees want their organization to be safe for the environment. This is due to the specificity of the sector (chemistry) and the numerous trainings conducted. However, the state of the system itself leaves much to be desired. Too many employees do not know the environmental objectives or environmental improvement plans. Responses were spread almost evenly for the question concerning the need to document events, activities related to system maintenance, which undoubtedly has a direct impact on environmental awareness.

This means that the system is not quite properly maintained (it probably lacks knowledge and proper communication). The analysis of the documentation shows otherwise - the system is properly maintained. However, in the period under consideration, there were no preventive measures, which are a kind of hologram of system awareness. Decision-makers rely on the reports from audits and reviews to learn about the need to improve environmental awareness. Therefore, their knowledge is very limited. In addition to analyzing the documentation, surveys are needed in the organization to understand the employees' feedback. Management derives knowledge only from audits, there were no dual studies based on audits and surveys. The introduction of surveys will allow for a more complete view of one side of the state of the system and, on the other hand, a real increase in the awareness of employees as well as executives.

For various reasons, the system is maintained by the environmental services but is not reflected in the awareness of employees (their knowledge of the actions taken). Previous studies have shown that managing persons not always want to effectively improve environmental performance, but they tend to satisfy their stakeholders. With this course of action, these systems are only implemented in the 
form of documentation (Simpson \& Sroufe, 2014). This is most likely to be the case in the organization in question and needs to be further investigated.

\section{REFERENCES}

Alomari, M. \& Ibraheem, A. (2019). Environmental performance measurement review of indicators and obstacles. International Journal of Financial Management, 9(3), 1-8.

Bugdol, M., Puciato, D. \& Borys, T. (2020). Environmental management systems in the context of sustainable development: The identification of open problems. Problemy Ekorozwoju - Problems of Sustainable Development, 15(2), 131-142.

Easterby-Smith, M., Thorne, R. \& Jackson, P.R. (2015). Management and Business Research. Los Angeles-Singapore: Sage.

Giudici, G., Guerini, M. \& Rossi-Lamastra, C. (2019). The creation of cleantech startups at the local level: The role of knowledge availability and environmental awareness. Small Business Economics, 52(4), 815-830. https://doi. org/10.1007/s11187-017-9936-9/.

ISO 14001:2015.7.3. Systemy zarządzania środowiskowego. Wymagania i wytyczne stosowania.

Kollmuss, A. \& Agyeman, J. (2002). Mind the gap: Why do people act environmentally and what are the barriers to pro-environmental behavior? Environment Education Research, 8(3), 239-260. https://doi.org/10.1080/13504620220145401/.

Law, M.M.S., Hills, P. \& Hau, B.C.H. (2017). Engaging employees in sustainable development: A case study of environmental education and awareness training in Hong Kong. Business Strategy \& the Environment (John Wiley \& Sons, Inc), 26(1), 84-97. https://doi.org/10.1002/bse.1903/.

Papagiannakis, G. \& Lioukas, S. (2018). Corporate environmental management: Individual-level drivers and the moderating role of charismatic leadership. European Management Review, 15(4), 475-489. https://doi.org/10.1111/ emre.12134/.

Safari, A., Salehzadeh, R., Panahi, R. \& Abolghasemian, S. (2018). Multiple pathways linking environmental knowledge and awareness to employees' green behavior. Corporate Governance: The International Journal of Effective Board Performance, 18(1), 81-103. https://doi.org/10.1108/CG-08-2016-0168/.

Severo, E.A., Guimarães, J.C.F.D., Dellarmelin, M.L. \& Ribeiro, R.P. (2019). The influence of social networks on environmental awareness and the social 
responsibility of generations. BBR. Brazilian Business Review, 16(5), 500-518. https://doi.org/10.15728/bbr.2019.16.5.5/.

Simpson, D. \& Sroufe, R. (2014). Stakeholders, reward expectations and firms' use of the ISO14001 management standard. International Journal of Operations \& Production Management, 34(7), 830-852. https://doi.org/10.1108/ IJOPM-02-2012-0063/.

Specq, F. (2016). Environmental Awareness and the Design of Literature. Studies in Environmental Humanities. Leiden: Brill/Rodopi.

Tocan, M. (2016). Analysis of the ISO 14001 environmental management system diffusion. Internal Auditing \& Risk Management, 11(3), 82-90.

Tursynbayeva, B.Z., Mukhambetkaliyeva, G.M., Auyesbay, K.A. \& Baigabylov, N.O. (2020). National policy and the media in the formation of environmental awareness among students of Kazakhstan. Media Watch, 11(3), 428-438. https://doi.org/10.15655/mw/2020/v11i3/202929/.

Yucedag, C., Kaya, L.G. \& Cetin, M. (2018). Identifying and assessing environmental awareness of hotel and restaurant employees' attitudes in the Amasra District of Bartin. Environmental Monitoring \& Assessment, 190(2), 1. https://doi. org/10.1007/s10661-017-6456-7/.

Zeynep, Ü.N.L.Ü. (2020). Analysis of short films of prospective teachers on environmental awareness. International Electronic Journal of Environmental Education, 10(2), 136-146.

\title{
ZWIAZZEK MIĘDZY ŚWIADOMOŚCIA ŚRODOWISKOWA PRACOWNIKÓW A OBECNYM SYSTEMEM ZARZĄDZANIA ŚRODOWISKOWEGO
}

\begin{abstract}
Abstrakt
Tło. Dotychczas ukazało się wiele publikacji dotyczących systemów zarządzania środowiskowego. Wdrożony i utrzymywany system powinien wpływać na świadomość środowiskową pracowników. Powstaje jednak pytanie, czy robi to skutecznie, a jeżeli tak, to w jakim stopniu. Dotychczasowe piśmiennictwo podkreśla znaczenie i rolę świadomości w tym zakresie. Zainteresowanie autora ta tematyką zostało ujęte w kontekście relacji między tym, jakiej informacji dostarcza dokumentacja systemowa (raporty z przeprowadzonych audytów), a rzeczywistą świadomością ekologiczną i środowiskową pracowników oraz kadry kierowniczej.

Cele badawcze. Zasadniczym celem niniejszego artykułu było ustalenie zwiąku między stanem systemu zarządzania środowiskowego a świadomością środowiskową użytkowników. Jako zalecenie wynikające z przeprowadzonych badan przyjęto
\end{abstract}


konieczność wsparcia dokumentacji systemowej ankietowaniem użytkowników w celu podniesienia świadomości i usprawnienia systemu.

Metodologia. Do zebrania i analizy danych wykorzystano przegląd literatury, dokumentacji poaudytowej oraz ankiety.

Kluczowe wnioski. Z przeprowadzonych badań wynika, że zdecydowana większość pracowników chce, aby ich organizacja była bezpieczna dla środowiska. Jednak w praktyce wielu z nich nie zna celów środowiskowych ani planów poprawy stanu środowiska. Oznacza to, że system nie jest optymalnie utrzymywany. Decydenci opierają się na raportach z audytów i przeglądów środowiskowych, aby dowiedzieć się o potrzebie poprawy świadomości ekologicznej. Oprócz analizy dokumentacji w organizacji niezbędne jest zastosowanie ankiet, ponieważ występuje dychotomia między informacjami pochodzącymi z raportów poaudytowych a rzeczywistym poziomem świadomości środowiskowej pracowników.

Słowa kluczowe: świadomość ekologiczna, przemysłowe systemy środowiskowe, zarządzanie środowiskowe, przemysł chemiczny. 